\title{
EMULSION PROCESS OPTIMIZATION OF CHIA OIL WITH CHEESE WHEY FOR ENCAPSULATION
}

\section{ADRIANI CRISTINA FELIPE DOS SANTOS ${ }^{1}$, TANISE PILETTI $^{2}$, DANIEL NEUTZLING} LEHN $^{3}$ and CLAUCIA FERNANDA VOLKEN de SOUZA ${ }^{4}$

\author{
${ }^{1}$ Centro Universitário Univates, Laboratório de Biotecnologia de Alimentos. \\ ${ }^{2}$ Centro Universitário Univates, Laboratório de Biotecnologia de Alimentos. \\ ${ }^{3}$ Centro Universitário Univates, Curso de Engenharia de Alimentos. \\ ${ }^{4}$ Centro Universitário Univates, Programa de Pós-graduação em Biotecnologia. \\ Email: adrysantos12@hotmail.com
}

\begin{abstract}
Chia seed is an excellent source of protein, rich in fatty acids and natural antioxidants. Its oil contains omega - 3 and 6 , essential for the prevention of cardiovascular and inflammatory diseases. The aim of this study was to obtain a stable emulsion from chia oil and whey for use in microencapsulation techniques. A $2^{3}$ experimental design was used for emulsions preparation. The independent variables were the stirring time and both whey and oil concentrations. The emulsions were stored at 4, 25 and $55^{\circ} \mathrm{C}$ to evaluate their stability. The emulsions stored at $4^{\circ} \mathrm{C}$ showed more stability. The emulsion with $25 \% \mathrm{w} / \mathrm{w}$ chia oil and $24 \% \mathrm{w} / \mathrm{w}$ whey was stable over 24 hours at 4 to $55^{\circ} \mathrm{C}$. The results demonstrated that it is possible to emulsify the chia oil with cheese whey with a view to encapsulation.
\end{abstract}

\section{INTRODUTION}

Chia (Salvia Hispanica L.) is a native seed of southern Mexico. The fatty acids from chia oil are highly unsaturated, rich in linoleic acid (17-26\%) and $\alpha$-linolenic acid (50-57\%) (omega3) (Ayerza et al., 1995). Omega-3 fatty acid is good for health, because they have important physiological roles such as their ability to decrease the risks of cardiovascular disease, diabetes, 


\section{9 a 22 de outubro de 2014 \\ Florianópolis/SC}

inflammatory bowel diseases, and rheumatoid arthritis (McClementns et al., 2007). On the other hand, oils rich in unsaturated fatty acids are highly sensible to oxidative deterioration and consequent production of undesirable flavor (Augustin et al., 2006). But chia oil can be enhanced through microencapsulation (Fuchs et al., 2006).

Microencapsulation it's a way to package materials in the form of micro-particles, and has developed within the pharmaceutical, chemical, food and many other industries. The most encapsulation technique for food products is spray drying (Jafari et al., 2008). This process involves the coating of a pure or a mixture into another material. The encapsulated material is called as the core material or actives, and the coating can be denominate wall material. The adequate selection of the wall material is a critical point in the microencapsulation, because it depends on what is encapsulated, the release mechanism, and where will be applied (PedrozaIslas et al., 1999). Some examples of wall material are modified starch, maltodextrin, gum (Gibbs et al., 1999) and cheese whey (Na et al., 2011).

Between the years 2000 to 2010 were produced about 745,000 tons of cheese under Federal Inspection (SIF) in Brazil (Abiq, 2014). This cheese production, taking into consideration that the whey is $90 \%$ of the volume used in the manufacture of cheese and $10 \mathrm{~L}$ of milk are required to produce $1 \mathrm{~kg}$ of cheese on average generate a volume equivalent to 6,705,000 tons of whey. If the whey is aimed directly into rivers or sewer becomes a major environmental problem because due to the high content of organic matter, provides a biochemical oxygen demand (BOD) of 30 to 50 $\mathrm{g} / \mathrm{L}$ and a chemical oxygen demand (COD) of 50 to $80 \mathrm{~g} / \mathrm{L}$ (Almeida et al., 2003; Siso, 1996). The protein portion contains about 50\% $\beta$-lactoglobulin, $25 \% \alpha$-lactalbumin and $25 \%$ of other proteins, including immunoglobulins (Fitzsimons et al., 2006). The cheese whey proteins have a high content of essential amino acids, in particular lysine, threonine, tryptophan, phenylalanine and tyrosine (Liu et al., 2000).

Microencapsulation of a well prepared and stable emulsion is essential to success of later drying process in terms of the uniformity of droplet distribution and covering effects of wall materials emulsifiers are often to facilitate formation of emulsion and enhance their stability (Liu et al., 2011). Gum arabic is one of wall materials used in the microencapsulation of oils. Because it is a natural gum, with good emulsifying properties, since they have a little content of protein in their composition. This gum has a high solubility and a low viscosity in aqueous solutions, wich facilitates the spray drying (Tonon et al., 2010). Lecithin has been used to obtain a stable emulsion because contains both hydrophilic and hydrophobic groups on the same molecule. Lecithin will lower the interfacial tension between the two phases and reduce the pressure gradients required to disrupt the droplets during emulsification process (Mezdour et al., 2010; Yamamoto et al., 1997).

The experimental design of emulsion process can be used as a way to determine and quantify the influence of the variables on the desired responses. This methodology reduces the number of experiments and improves the quality of information obtained through the results, allowing analysis of factors simultaneously (Rodrigues et al., 2009). 
The objective of this work was to study the influence of chia oil and cheese whey concentrations on the preparation and stability of emulsions in order to encapsulation by spray drying. Stability under different storage conditions, microstructure and turbidity of emulsions were analyzed as responses.

\section{MATERIALS AND METHODOS}

\subsection{Materials}

Chia oil was purchased from Girioil Agroindústria Ltda (Rio Grande do Sul, Brazil). Arabic gum was purchased from Labsynth Produtos para Laboratório Ltda (São Paulo, Brazil). Soy was purchased from Bremil Indústria de Suplementos Alimentares Ltda (Rio Grande do Sul, Brazil). Cheese whey was provided by BRF SA (Rio Grande do Sul, Brazil). Sodium dodecyl sulphate (SDS) was bought from Vetec (Rio de Janeiro, Brasil). Citric acid was acquired in a local store.

\subsection{Methodos}

Preparation of emulsion: An experimental design $2^{3}$ was used to optimize the emulsion process. Three variable conditions were applied: time of agitation and oil and cheese whey concentrations, resulting a total of 17 experiments (Table 1). Arabic gum $(2 \% \mathrm{w} / \mathrm{w})$ and soy lecithin $(0.5 \% \mathrm{w} / \mathrm{w})$ concentrations were kept constant through all the experiments.

Tabela 1 - Condições experimentais

\begin{tabular}{|c|c|c|c|c|c|c|}
\hline Experiment & $\begin{array}{c}\text { Time } \\
(\min ) \\
\left(\mathrm{x}_{1}\right)\end{array}$ & $\begin{array}{c}\text { Chia oil } \\
(\% \mathrm{w} / \mathrm{w}) \\
\left(\mathrm{x}_{2}\right)\end{array}$ & $\begin{array}{c}\text { Cheese whey } \\
(\% \mathrm{w} / \mathrm{w}) \\
\left(\mathrm{x}_{3}\right)\end{array}$ & $\begin{array}{c}\text { Time } \\
(\min ) \\
\left(X_{1}\right)\end{array}$ & $\begin{array}{c}\text { Chia oil } \\
(\% \mathrm{w} / \mathrm{w}) \\
\left(\mathrm{X}_{2}\right)\end{array}$ & $\begin{array}{c}\text { Cheese whey } \\
(\% \mathrm{w} / \mathrm{w}) \\
\left(\mathrm{X}_{3}\right)\end{array}$ \\
\hline 1 & -1 & -1 & -1 & 48 & 10 & 8 \\
\hline 2 & -1 & -1 & 1 & 48 & 10 & 24 \\
\hline 3 & -1 & 1 & -1 & 48 & 25 & 8 \\
\hline 4 & -1 & 1 & 1 & 48 & 25 & 24 \\
\hline 5 & 1 & -1 & -1 & 72 & 10 & 8 \\
\hline 6 & 1 & -1 & 1 & 72 & 10 & 24 \\
\hline 7 & 1 & 1 & -1 & 72 & 25 & 8 \\
\hline 8 & 1 & 1 & 1 & 72 & 25 & 24 \\
\hline 9 & -1.68 & 0 & 0 & 40 & 17.5 & 16 \\
\hline 10 & 1.68 & 0 & 0 & 80 & 17.5 & 16 \\
\hline 11 & 0 & -1.68 & 0 & 60 & 5 & 16 \\
\hline 12 & 0 & 1.68 & 0 & 60 & 30 & 16 \\
\hline 13 & 0 & 0 & -1.68 & 60 & 17.5 & 2 \\
\hline
\end{tabular}




\section{9 a 22 de outubro de 2014 \\ Florianópolis/SC}

\begin{tabular}{ccccccc}
14 & 0 & 0 & 1.68 & 60 & 17.5 & 30 \\
15 & 0 & 0 & 0 & 60 & 17.5 & 16 \\
16 & 0 & 0 & 0 & 60 & 17.5 & 16 \\
17 & 0 & 0 & 0 & 60 & 17.5 & 16 \\
\hline
\end{tabular}

Arabic gum was dispersed in distilled water at $60^{\circ} \mathrm{C}$ under magnetic stirring for 3 minutes. The solution was cooled to $20^{\circ} \mathrm{C}$, then the cheese whey powder was dispersed under magnetic stirring for 3 minutes. The solution was placed in a cold shaker orbital $(300 \mathrm{rpm})$ for $12 \mathrm{~h} \mathrm{at} 20^{\circ}$ $\mathrm{C}$ to ensure complete hydration. The resulting mixture was adjusted to $\mathrm{pH} 4.2$ using citric acid $50 \%(w / v)$. The oil phase containing the chia oil and the soy lecithin was then blended with the cheese whey and Arabic gum solution using a stirring-type homogenizer, under a constant speed rotation at $20.000 \mathrm{rpm}$. During the homogenization process, the mixture was kept under ice-water bath, with a controlled temperature around $1 \pm 0.5^{\circ} \mathrm{C}$.

\subsection{Analysis}

Microscopic analysis: Emulsions were analyzed under a biological microscope a $40 \times$ magnification.

Stability under storage: For each emulsion, three test tubes were filled with $10 \mathrm{~mL}$ of the emulsion and then hermetically closed. They were stored vertically in three different temperatures $\left(4,24,55^{\circ} \mathrm{C}\right)$. Tubes were measured immediately after preparation of the emulsion and after 24 hours. With this analysis it was possible to obtain the values of creaming index (C.I.) of emulsions (Roland et al., 2003).

$$
\mathrm{C} . \mathrm{I} \%=\frac{H 1}{H 0} \times 100
$$

Where: $H_{0}$ represents the emulsion initial height and $H_{1}$ is the upper phase height.

Turbidity Measurements: A volume of $0.1 \mathrm{~mL}$ of witch emulsion was diluted with $4.9 \mathrm{~mL}$ of solution of sodium dodecyl sulphate (SDS) concentration of $0.1 \%$. The absorbance of the diluted emulsions was determined at $500 \mathrm{~nm}$. Emulsion stability (ES) was estimated by the durability of emulsion over 10 minutes, and expressed as $\mathrm{ES}(\%)=\left(\mathrm{Abs}_{10 \mathrm{~min}} / \mathrm{Abs}_{0} \mathrm{~min}\right) \times 100$. Four replicates of each measurement were made.

\section{RESULTS AND DISCUSSION}

\subsection{Microscopic analysis}

In the analysis of microstructure (Figure 1) was observed in Experiments 4, 8 and 14 similarities 
in particle size, small and close together. These experiments showed a good stability. In the other hand, the Experiment 13 showed a low stability and the particles generated were larger and more dispersed.

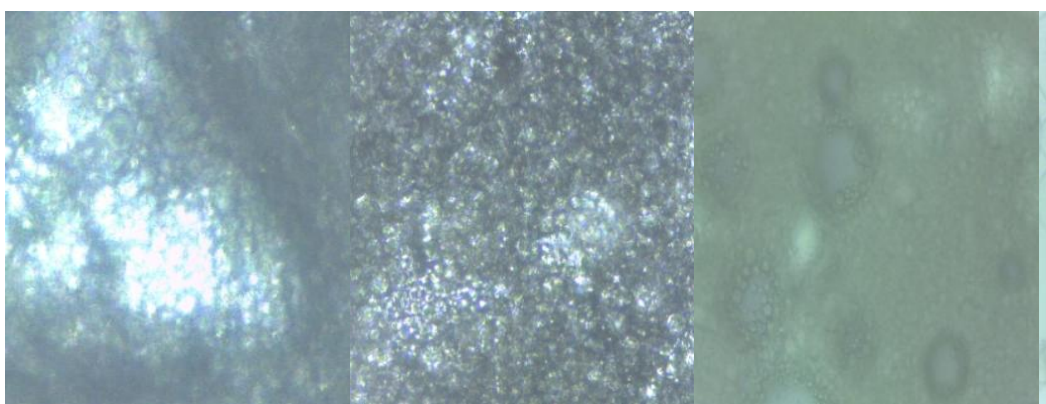

(A) (B)
(C)

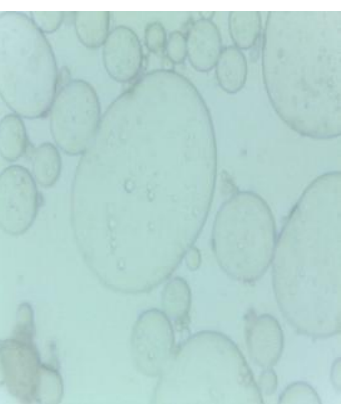

(D)

Figure 1- Microscope images: (A) Experiment 8, (B) Experiment 4, (C) Experiment 14 and (D) Experiment (13).

\subsection{Stability under storage}

The results of stability analysis as shown in Table 2 demonstrated that the Experiment 8 was the most stable, containing $25 \%$ (w/w) of chia oil and $24 \%$ (w/w) of cheese whey, remaining completely stable after 24 hours at 4 to $55^{\circ} \mathrm{C}$. In the Experiment 4 chia oil and cheese whey concentrations were the same that Experiment 8, but the stirring time was not enough to generate a stable emulsion. The Experiment 14, which contained the highest level of whey showed a low Cream Index, indicating the importance of the whey at emulsion formation. The lower temperature favors the stability of emulsions.

Table 2 - Emulsions cream index $(\%)$ results in different storage temperatures

\begin{tabular}{|c|c|c|c|}
\hline Experiment & $\begin{array}{l}4^{\circ} \\
C\end{array}$ & $\begin{array}{l}25^{\circ} \\
C\end{array}$ & $\begin{array}{l}55^{\circ} \\
\mathrm{C}\end{array}$ \\
\hline 1 & 89.23 & 90.76 & 92.30 \\
\hline 2 & 85.07 & 82.08 & 82.08 \\
\hline 3 & 95.45 & 96.96 & 93.93 \\
\hline 4 & 1.75 & 14.03 & 10.52 \\
\hline 5 & 85.71 & 80.00 & 81.42 \\
\hline 6 & 96.66 & 91.66 & 96.66 \\
\hline 7 & 88.40 & 89.85 & 86.95 \\
\hline 8 & 00.00 & 10.00 & 00.00 \\
\hline 9 & 90.76 & 84.61 & 89.23 \\
\hline
\end{tabular}




\section{9 a 22 de outubro de 2014 \\ Florianópolis/SC}

\begin{tabular}{llll}
10 & 81.94 & 83.33 & 88.87 \\
11 & 78.57 & 84.28 & 78.57 \\
12 & 97.33 & 90.66 & 86.66 \\
14 & 1.53 & 7.69 & 4.61 \\
16 & 80.00 & 85.71 & 91.42 \\
17 & 77.46 & 83.09 & 91.54 \\
\hline
\end{tabular}

\subsection{Turbidity Measurements}

The relationship between turbidity and particle size of the emulsions presented a nonlinear behavior, so it is difficult to interpret the turbidity results. One of the factors that can intervene in this imprecision is the multiple scattering of light by the dispersed oil globules in especially when oil globules were small (Kinsella et al., 1978).

\section{CONCLUSIONS}

The results showed that is it possible to obtain stable emulsions of chia oil using cheese whey, Arabic gum and lecithin. The ideal composition for a stable emulsion was chia oil $25 \%$ (w/w) and cheese whey $24 \%$ (w/w). Low temperatures contribute to emulsions stability.

\section{REFERENCES}

ABIQ. Associação Brasileira das Indústrias de Queijos. Avanços e perspectivas da indústria brasileira de queijos. Disponível em: <http://www.abiq.com.br/imprensa_ler.asp?codigo=1003\&codigo_categoria=2\&codigo_subcateg oria=17>. Accessed in: 23 April, 2014.

ABIQ. Associação Brasileira das Indústrias de Queijos. Disponível em: <http://www.scotconsultoria.com.br/noticias/artigos/28592/producao-de-queijos-no-brasil-deveultrapassar-10-milhao-de-toneladas-em-2013.htm>. Accessed in: 23 April, 2014.

ALMEIDA, E. S. et al. Remediação do efluente da indústria de queijos combinando processo biológico (produção de proteínas celulares) e processo físico-químico (ozônio). In: Congresso Brasileiro de engenharia sanitária e ambiental, 2003. Joinville/PR: ABES, 14 a 19 de setembro de 2003.

AYERZA, R. Oil content and fatty acid composition of chia (Salvia hispanica L.) from five northwestern locations in Argentina. Journal of the American Oil Chemists Society, v. 72, p. 1079-1081. 1995. 
CARNEIRO, H.C.F.; TONON, R.V.; GROSSO, C.R.F.; HUBINGER, M.D. Encapsulation Efficiency and oxidative stability of flaxseed oil microencapsulated by spray drying using different combinations of wall materials. Journal of Food Engineering. v. 115, p. 443-451, 2013.

FITZSIMONS, S. M.; MULVIHILL, D. M.; MORRIS, E. R. Denaturation and aggregation processes in thermal gelation of whey proteins resolved by differential scanning calorimetry. Food Hydrocolloids, Oxford, v. 11, p. 62-69, 2006.

FUCHS, M., TURCHIULI, C., BOIHIN, M., CULIVELIER, M.E., ORDONNAUD, C., PEYRAT-MAILLARD, M.N., DUMOULIN, E. Encapsulation of oil in powder using spray drying and fluidized bed agglomeration. Journal of Food Engineering, v.75, p. 27-35. 2006.

GIBBS, B.F. Encapsulation in the food industry: a review. J. Food Sci. Nutr., v.50, p.213-224, 1999.

JAFARI, S.M., ASSODPOOR, E., He, Y., BHANDARI, B. Encapsulation Efficiency of Food Flavours and Oils during Spray Drying. Drying Technology, v. 26, p. 816-835, 2008.

LIU, G.; XIONG, Y. L.; BUTTERFIELD, D. A. Chemical, physical, and gel forming properties of oxidized myofibrils and whey and soy proteins isolate. Journal of Food Science, v. 65, p. 811$818,2000$.

LIU, T., YANG T. Optimization of emulsification and microencapsulation of evening primrose oil and its oxidative stability during storage by response surface methodology. Journal of Food Quality, v. 34, p. 64-73, 2010.

MEZDOUR, S., DESPLANQUES S., RELKIN, P. Effects of residual phospholipids on surface proprieties of a soft-refined sunflower oil: application to stabilization of sauce-types emulsions. Food Hydrocolloids, v. 25, p. 613-619, 2011.

MCCLEMENTS, D.J., Decker, E.A., Weiss, J. Emulsion-based delivery systems for lipophilic bioactive components. Journal of Food Science v. 72, p. 109-124, 2007.

NA, H., KIM, J., LEE, K. Encapsulation of fish oil Using cyclodextrin and whey protein concentrate. Biotechnology and Bioprocess Engineering, v. 16, p. 1077-1082, 2011.

PEARCE, K. N.; KINSELLA, J. E. Emulsifying properties of proteins: evaluation of a turbidimetric technique. J. Agric. Food Chem., v. 26, p. 716-723, 1978

PEDROZA-ISLAS, R., VERNON-CARTER, E.J., DURÁN-DOMÍNGUEZ,C, TREJOMARTINEZ, S. Using biopolymer blends for shrimp feedstuff microencapsulation. I. Particle size, morphology and microstructure of microcapsules. Food Research International, v. 32, p. 367-374, 1991. 
RODRIGES, M.I., LEMMA, A. F.Planejamento de Experimentos e Otimização de Processos. São Paulo: Editora Casa do Espírito Amigo Fraternidade Fé e Amor, 2009.

ROLAND, I., PIEL, G., DELATTRE, L., EVRARD, B. Systematic characterizantion of oil-inwater emulsions for formulations design. International Journal of Pharmaceutics, v. 236, p. 8594, 2003.

TONTO, R.V., GROSSO, C.R.F., HUBINGER, M.D. Influence of emulsion composition and inlet air temperature on the microencapsulation of flaxseed oil by spray drying. Food Research International, v. 44, p. 282-289, 2011.

YAMAMOTO, Y., ARAKI, M. Effects of lecithin addition in oil or water phase on the stability of emulsions made with whey proteins. Biosci. Biotech. Biochem., v. 61, p. 1791- 1795, 1997. 